\title{
Impact of PRE- and POST herbicide on purple nut sedge (Cyperus rotundus L.) control and plasticulture tomato yields
}

\author{
Maryam Bayat $^{1 *}$, Meisam Zargar ${ }^{1}$, Elena Pakina ${ }^{1}$, Marina Lyashko ${ }^{1}$, and Bhagirath S. Chauhan ${ }^{2}$ \\ ${ }^{1}$ RUDN University, Institute of Agriculture, Department of AgroBiotechnology, 117198 Moscow, Russia. \\ "Corresponding author (bayat_m@pfur.ru). \\ ${ }^{2}$ The University of Queensland, Queensland Alliance for Agriculture and Food Innovation (QAAFI), Gatton, Queensland 4350, Australia.
}

Received: 30 June 2020; Accepted: 7 September 2020; doi:10.4067/S0718-58392021000100046

\begin{abstract}
Purple nut sedge (Cyperus rotundus L.) is a problematic weed in plasticulture tomato (Solanum lycopersicum L.) production in Iran as it is difficult to control due to its ability to penetrate plastic mulch. Field trials were carried out at the experimental area of the state farm Safadasht, Shahriar region, Iran, over the fall of 2015 and spring of 2016 to investigate PRE- and POST herbicide programs (PRE transplanting, POST transplanting, and combination of PRE- and POST transplanting) to control purple nut sedge in plasticulture tomato production. PRE herbicide treatment metribuzin and $(S)$-metolachlor were not effective when applied alone, and did not reduce purple nut sedge plants compared to the weedy control. POST transplanting application of halosulfuron did not significantly affect purple nut sedge plants at 12 wk after application (WAA) in the fall 2015, but treatment favorably reduced density of purple nut sedge at 16 WAA in both seasons. PRE transplanting application of metribuzin or $(S)$-metolachlor plus POST halosulfuron exerted the greatest control, and purple nut sedge numbers were eventually diminished in both seasons. Experimental treatments did not negatively affect tomato height and yields. Based on our findings, multiple PRE and POST herbicide programs were effective in greater purple nut sedge suppression compared to the lone application of PRE and POST herbicides. The herbicides were selected due to routine use by tomato producers in the area. Using active ingredients from the various herbicide families with different modes of action could facilitate effective management of herbicide-resistant purple nut sedge in tomato fields.
\end{abstract}

Key words: Plasticulture, PRE- and POST herbicides, purple nut sedge, tomato, weed control.

\section{INTRODUCTION}

Tomato (Solanum lycopersicum L.) is one of the principal vegetable crops produced in Iran with an annual output of approximately 150 million tons (Shirdel et al., 2014; Zenga et al., 2020). The use of polyethylene mulch in crop production can significantly increase yield, minimize nutrient leaching, enable sustainable vegetable production and lessen herbicide dependence and total application. In tomato production, polyethylene mulches provide considerable control of most grass and broadleaved weeds; nonetheless, these weeds generally appear through the planting hole in the mulch (Dittmar et al., 2010; Mafakheri et al., 2012). Purple nut sedge (Cyperus rotundus L.) has been found to be a problematic weed menacing plasticulture tomato cultivation, since it emerges through the crop hole and also perforates the polyethylene mulch (Adcock et al., 2008; Dittmar et al., 2012). Boyd (2016) validated that purple nut sedge pierces through the plastic mulch between the tomato rows and emerge through the crop holes. 
POST herbicides are necessary for nut sedge control, nonetheless few herbicides can be safely used pre or post transplant in tomato cultivation (Manning and Fennimore, 2001; Boyd, 2016; Merino et al., 2020). For this reason, most farmers apply PRE transplanting herbicides such as metribuzin and (S)-metolachlor (Devkota et al., 2013), and POST transplanting herbicides such as halosulfuron (Haar et al., 2002) for nut sedge suppression (Freeman et al., 2016; Boyd and Dittmar, 2018). Halosulfuron is an active ingredient belonging to the sulfonylurea group with varying levels of purple nut sedge control in tomato and other vegetable crops. Adcock et al. (2008) reported effective control of nut sedge weed population due to POST transplant application of halosulfuron. A study by Vencill et al. (1995) exhibited nonsignificant difference in weed biomass, shoots and roots of purple nut sedge when halosulfuron was applied either to foliage or the soil. The plasticulture production approach is generally dependent on herbicide use, since cultivation is hindered by the presence of the polyethylene mulch. Hence, to achieve optimum weed management several herbicide applications are required. POST herbicide options such as glyphosate application prior to sowing are favored by farmers (Vasilakoglou et al., 2018). Various PRE- and POST active ingredients are registered for purple nut sedge and yellow nut sedge (Cyperus esculentus L.) control (Pereira et al., 1987; Boyd and Dittmar, 2018). These herbicides only provide inconsistent or shortterm control of nut sedge plants (Dittmar, 2013; Bayat et al., 2019).

Halosulfuron is a safe and pragmatic POST transplant herbicide in tomato fields (Jennings, 2010; Pliushchikov et al., 2019), and is a viable option used in various PRE- and POST combinations for prolonged purple nut sedge suppression. Herbicide programs integrating both PRE and POST herbicides are highly recommended for effective control of nut sedge weeds. For instance, Boyd and Dittmar (2018) stated that spraying (S)-metolachlor combined with halosulfuron in tomato fields significantly reduces nut sedge weed density. Moreover, Devkota et al. (2013) reported satisfactory yellow nut sedge control up to 90\% owing to the application of PRE (S)-metolachlor plus POST trifloxysulfuron or halosulfuron.

There is need to identify the most effective multiple herbicide programs for purple nut sedge control in plasticulture tomato cultivation. The principal objective of this study was to investigate the efficacy of multiple PRE transplanting herbicides applied alone or followed by the POST herbicide halosulfuron in plasticulture tomato production.

\section{MATERIALS AND METHODS}

\section{Site description, experimental design, and site management}

This study consisted of two field experiments that were laid out in separate experimental fields in west of Tehran namely Shahriar region (5050' E, 3540’ N; $1130 \mathrm{~m}$ a.s.1.), Iran, in 2015 and 2016. Soil samples were randomly taken from each replicate and from each experiment, at a depth of $25 \mathrm{~cm}$ before sowing. The samples were dried at $55{ }^{\circ} \mathrm{C}$, ground, and analyzed by standard methods (Clemson University Agricultural Service Laboratory, Clemson, South Carolina, USA). The soil was classified as loamy sand (fine-loamy, thermic Typic Kandiudults) with a pH of 6.4 and organic matter of 1.1\%.

Experiments were conducted in a randomized complete block design with four blocks. Plots were $0.85 \mathrm{~m}$ wide raised beds measuring $6 \mathrm{~m}$ in length. Beds were prepared in the middle of July 2015 (fall) and the end of January 2016 (spring). A single drip tape was installed in the center at $3 \mathrm{~cm}$ below the soil surface. All beds were fumigated with $220 \mathrm{~kg} \mathrm{ha}^{-1} 40 \%$ 1,3-dichloroprop-1-ene plus trichloro(nitro)methane (Pic-Clor 60, TriCal Inc., Hollister, California, USA) using a threeshank fumigation rig. Holes were punched in a single row with $0.60 \mathrm{~m}$ spacing with a mechanical hole puncher. Tomato (Solanum lycopersicum L.) 'Ezmir' was transplanted after punching the sowing holes on 27 August 2015 and 3 March 2016. Herbicides involved the POST transplanting active ingredient halosulfuron (3-chloro-5-[(4,6-dimethoxypyrimidin2-yl)carbamoylsulfamoyl]-1-methylpyrazole-4-carboxylic acid) at $48 \mathrm{~g} \mathrm{ai} \mathrm{ha}^{-1}$, and two PRE transplanting herbicides metribuzin (4-amino-6-tert-butyl-3-methylsulfanyl-1,2,4-triazin-5-one) $550 \mathrm{~g}$ ai ha-1 and (S)-metolachlor (2-chloro- $N$ (2-ethyl-6-methylphenyl)- $N$-[(2S)-1-methoxypropan-2-yl]acetamide) $1020 \mathrm{~g} \mathrm{ai} \mathrm{ha}^{-1}$. A detailed description of herbicide treatments is given in Table 1.

Following soil fumigation, PRE transplanting herbicides were applied and beds were immediately covered with plastic mulch. The POST transplanting herbicide halosulfuron was applied on tomato plants when tomato plants were at flowering stage. All herbicide treatments were sprayed with a backpack sprayer (Bellspray Inc., Opelousas, Louisiana, USA) with a pressure of 0.25 MPa. Its boom was fitted with a single 8002VS nozzle (TeeJet Technologies, Wheaton, Illinois, USA) and herbicides were applied at a spray volume of $210 \mathrm{~L} \mathrm{ha}^{-1}$ water. Weedy control plots were conducted in each replicate of each experiment for comparison. In the weedy control, no weeding was done. Herbicides were sprayed on both sides of the bed and directly at the base of the tomato plants. 
Table 1. Herbicide treatments applied PRE- and POST transplanting at the base of tomato plants at Shahriar region, Iran, in 2015 and 2016.

\begin{tabular}{|c|c|c|c|c|}
\hline $\begin{array}{l}\text { Active } \\
\text { ingredient }\end{array}$ & $\begin{array}{c}\text { Rate } \\
\left(\mathrm{g} \text { ai ha }{ }^{-1}\right)\end{array}$ & Mode of action & Chemical name & Manufacturer \\
\hline \multicolumn{5}{|l|}{ PRE } \\
\hline Metribuzin & 550 & Photosystem II inhibitor & $\begin{array}{l}\text { 4-amino-6-tert-butyl-3- } \\
\text { methylsulfanyl-1,2,4-triazin-5-one }\end{array}$ & $\begin{array}{c}\text { Bayer CropScience, Research } \\
\text { Triangle Park, North Carolina } \\
\text { (http://www.cropscience.bayer.us) }\end{array}$ \\
\hline$(S)$-Metolachlor & 1020 & Long chain fatty acid inhibitor & $\begin{array}{c}\text { 2-chloro- } N \text {-(2-ethyl-6-methylphenyl)- } \\
N \text {-[(2S)-1-methoxypropan-2-yl] } \\
\text { acetamide }\end{array}$ & $\begin{array}{l}\text { Syngenta Crop Protection Inc., } \\
\text { Greensboro, North Carolina, USA }\end{array}$ \\
\hline \multicolumn{5}{|l|}{ POST } \\
\hline Halosulfuron & 48 & ALS inhibitor & $\begin{array}{c}\text { 3-chloro-5-[(4,6-dimethoxypyrimidin- } \\
\text { 2-yl)carbamoylsulfamoyl]-1- } \\
\text { methylpyrazole-4-carboxylic acid }\end{array}$ & $\begin{array}{c}\text { Gowan Company, Yuma, Arizona, } \\
\text { USA (http://gowanco.com) }\end{array}$ \\
\hline
\end{tabular}

ALS: Acetolactate synthase.

Crop injury was estimated visually 2 and 4 wk after application (WAA) using a scale from $0 \%$ to $100 \%$ (0\% no injury and $100 \%$ plant death) (Chaudhari et al., 2015). Chlorosis, necrosis, and leaf deformation were surveyed according to visual injury estimates. Tomato fruits were harvested on 28 November and 8 December 2015, and 27 May and 10 June 2016.

Tomatoes were graded according to diameter prior to weighing as small $(5.4-6.4 \mathrm{~cm}$ diameter), large $(6.4-7.0 \mathrm{~cm})$ and $x$-large $(>7.0 \mathrm{~cm})$. Marketable yield was the sum of the three fruit grades (Anonymous, 1991). Purple nut sedge shoots in whole plots were counted 4, 12, and 16 WAA in 2015 and 4 and 16 WAA in 2016. 6.5 to 7 cm diameter.

\section{Statistical analysis}

Data was analyzed in SAS version 9.2 (SAS Institute Inc., Cary, North Carolina, USA) using a mixed procedure with the block as the random factor. Data was checked for normality and constant variance prior to analysis. Experiments were analyzed separately as they were conducted in separate years and climate conditions were different between seasons. Treatment means were compared with the Tukey adjustment means of comparison at the 0.05 significance level. Tomato injury data was recorded at multiple dates and was analyzed with the function of the repeated statement.

\section{RESULTS AND DISCUSSION}

PRE and POST transplanting herbicide application had a significant effect on purple nut sedge control in both seasons. The PRE transplanting herbicides metribuzin and $(S)$-metolachlor did not decrease the presence of purple nut sedge plants compared to the weedy control when they were applied alone (Table 2). The lowest purple nut sedge control was detected for PRE transplanting herbicide metribuzin at all evaluation timings in 2015 and did not differ from the weedy control; however, this herbicide favorably reduced the purple nut sedge population at 16 WAA in 2016. POST transplanting application of halosulfuron did not reduce nut sedge counts significantly at 12 WAA in 2015; but, this herbicide reduced purple nut sedge plants at 16 WAA in 2015 and 2016 (Table 2).

Overall, the highest purple nut sedge control was attained when PRE transplanting herbicides metribuzin or $(S)$ metolachlor were applied in combination with POST halosulfuron application compared to the PRE transplanting treatments sprayed alone in 2015. Hence, weed control efficacy of all herbicide treatments at $16 \mathrm{WAA}$, except $(S)$-metolachlor, were similar to the weedy control and effectively diminished purple nut sedge density. (S)-metolachlor can significantly control nut sedge numbers (Adcock et al., 2008; Dittmar, 2013; Boyd, 2016), but this was not obtained in our study. Poor nut sedge control was due to the fact that some of the nut sedge plants had already emerged at the time of spray.

Weed control results indicated that density of purple nut sedge in 2015 was favorably higher than in 2016. Inconsistent weed control efficacy between seasons could be due to the variability of purple nut sedge density in experimental fields. In a study, Miller and Dittmar (2014) reported that control of a high density of nut sedge is difficult in plasticulture vegetable crops when relying on fomesafen or $(S)$-metolachlor PRE transplanting active ingredients alone. In our research, the herbicide combination composed of $(S)$-metolachlor or metribuzin as PRE transplanting herbicides with halosulfuron POST transplanting herbicide obtained the highest efficacy at almost all evaluation timings and consistently diminished the number of nut sedge plants. 
Table 2. Purple nut sedge counts following herbicide treatments in plasticulture tomato in Shahriar, Iran, in 2015 and 2016.

\begin{tabular}{|c|c|c|c|c|c|c|c|}
\hline \multirow[b]{2}{*}{ Active ingredient } & \multirow[b]{2}{*}{ Timing } & \multirow[b]{2}{*}{ Field rate } & \multicolumn{3}{|c|}{2015} & \multicolumn{2}{|c|}{2016} \\
\hline & & & 4 WAA & 12 WAA & 16 WAA & 4 WAA & 16 WAA \\
\hline & & $\mathrm{g}$ ai ha ${ }^{-1}$ & & 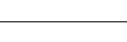 & $\mathrm{Nr}$ shoots $^{-2}$ & & $\bar{x}$ \\
\hline Weedy & - & - & $55 \mathrm{a}$ & $127 \mathrm{a}$ & $115 \mathrm{a}$ & $8 \mathrm{a}$ & $11 \mathrm{a}$ \\
\hline Halosulfuron & POST & 48 & $76 a$ & $82 \mathrm{ab}$ & $17 b$ & $6 a$ & $2 b$ \\
\hline Metribuzin & PRE & 550 & $50 \mathrm{a}$ & $82 \mathrm{a}$ & $86 a$ & $5 \mathrm{a}$ & $3 b$ \\
\hline Halosulfuron + metribuzin & $\mathrm{POST}+\mathrm{PRE}$ & $48+550$ & $18 \mathrm{a}$ & $7 \mathrm{c}$ & $3 b$ & $4 \mathrm{a}$ & $2 b$ \\
\hline$(S)$-Metolachlor & PRE & 1020 & $42 \mathrm{a}$ & $98 \mathrm{a}$ & $95 \mathrm{a}$ & $6 a$ & $8 \mathrm{ab}$ \\
\hline$(S)$-Metolachlor + halosulfuron & $\mathrm{PRE}+\mathrm{POST}$ & $1020+48$ & $39 a$ & $15 \mathrm{bc}$ & $2 b$ & $1 \mathrm{a}$ & $1 \mathrm{~b}$ \\
\hline P-value & - & - & 0.4412 & 0.0002 & 0.0025 & 0.1800 & 0.0091 \\
\hline Coefficient of variation, $\%$ & - & - & 2.91 & 8.99 & 4.90 & 7.07 & 11.08 \\
\hline
\end{tabular}

Means followed by different letters in each column are significantly different by Tukey's protected LSD (P $\leq 0.05)$.

WAA: Weeks after application.

Halosulfuron is an effective active ingredient for controlling purple nut sedge (Grichar et al., 2003; Freeman et al., 2016; Boyd and Dittmar, 2018; Yu et al., 2020). Halosulfuron is also effective for control of many different broadleaf and grass weeds in Iranian fields including goose grass (Eleusine indica [L.] Gaertn.), velvetleaf (Abutilon theophrasti L.) and barnyardgrass (Echinochloa crus-galli [L.] P. Beauv.) (Zand et al., 2011). The lowest level of nut sedge control was obtained when metribuzin or $(S)$-metolachlor were used alone in PRE transplanting applications (Table 2). In this regard, Boyd (2015) reported nut sedge control was inconsistent and varied over time and area when $(S)$-metolachlor was applied solely as PRE transplanting. Hence, application of the described PRE transplanting active ingredients alone in tomato fields might not be sufficient for long term sustainable weed management.

As a result, POST application of halosulfuron can provide purple nut sedge suppression after using PRE herbicides such as metribuzin or (S)-metolachlor (Yu et al., 2020). Blum et al. (2000) found that 35\% to 70\% nut sedge control was achieved through the use of a POST halosulfuron application in turf, whereas Grichar et al. (2003) indicated a 75\% to 95\% nut sedge control through a single application of halosulfuron in potato fields. Additionally, Bangarwa et al. (2009) reported that PRE transplant use of $(S)$-metolachlor provided about $80 \%$ yellow nut sedge control at 5 WAA, but this treatment had no favorable suppression efficacy on purple nut sedge density.

Effective weed management is critical in order to produce quality fruit at high levels of production (Zimdahl, 2004; Zargar et al., 2019a); as failure to do so can result in severe yield losses in tomato (Buckelew et al., 2006; Garvey et al., 2013). Visible yield injury results are given as an average of all evaluation timings in Table 3. Yield injury was $\leq 2 \%$ and plant height was not decreased by herbicide treatments. There was nonsignificant difference in tomato yield in all sampling dates. The critical weed-free period for tomato is about $5 \mathrm{wk}$ after transplanting (Garvey et al., 2013),

Table 3. Visible injury and height affected by herbicide treatments in plasticulture tomato in Shahriar, Iran.

\begin{tabular}{|c|c|c|c|c|c|c|}
\hline \multirow[b]{3}{*}{ Active ingredient } & \multirow[b]{3}{*}{ Timing } & \multirow[b]{3}{*}{ Field rate } & & & \multicolumn{2}{|c|}{ Plant height } \\
\hline & & & \multicolumn{2}{|c|}{ Yield injury } & 2015 & 2016 \\
\hline & & & 2015 & 2016 & 7 WAA & 4 WAA \\
\hline & & g ai ha ${ }^{-1}$ & 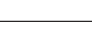 & - & 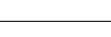 & - \\
\hline Weedy & - & - & 0 & 0 & 95.1 & 16.2 \\
\hline Halosulfuron & POST & 48 & 1 & 0 & 90.5 & 13.5 \\
\hline Metribuzin & PRE & 550 & 0 & 0 & 86.2 & 12.0 \\
\hline Halosulfuron + metribuzin & $\mathrm{POST}+\mathrm{PRE}$ & $48+550$ & 0 & 0 & 86.2 & 13.8 \\
\hline$(S)$-Metolachlor & PRE & 1020 & 0 & 1 & 90.5 & 14.2 \\
\hline$(S)$-Metolachlor + halosulfuron & PRE + POST & $1020+48$ & 2 & 0 & 89.3 & 14.1 \\
\hline P-value & - & - & 0.0051 & 0.0887 & 0.1113 & 0.0002 \\
\hline Coefficient of variation, $\%$ & - & - & 9.9 & 10.2 & 2.9 & 7.5 \\
\hline
\end{tabular}

Means followed by different letters in each column are significantly different by Tukey's protected LSD (P $\leq 0.05)$.

WAA: Weeks after application. 
Table 4. Efficacy of PRE- and POST transplanting herbicides on plasticulture tomato yield.

\begin{tabular}{|c|c|c|c|c|c|c|c|c|c|c|}
\hline \multirow[b]{2}{*}{ Active ingredient } & \multirow[b]{2}{*}{ Timing } & \multirow[b]{2}{*}{ Rate } & \multicolumn{4}{|c|}{2015} & \multicolumn{4}{|c|}{2016} \\
\hline & & & Small & Large & $\mathrm{x}$-large & Marketable & Small & Large & $\mathrm{x}$-large & Marketable \\
\hline & & $\mathrm{g}$ ai ha ${ }^{-1}$ & & & 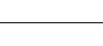 & $\mathrm{kg} \mathrm{pl}$ & $n t^{-1}$ & 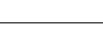 & & $\ldots$ \\
\hline Weedy & - & - & 0.70 & 1.30 & 6.70 & 8.70 & 0.24 & 1.01 & 2.85 & 4.10 \\
\hline Halosulfuron (halo) & POST & 48 & 0.71 & 1.39 & 6.75 & 8.85 & 0.22 & 0.89 & 3.84 & 4.95 \\
\hline Metribuzin (met) & PRE & 550 & 0.90 & 1.36 & 8.09 & 10.35 & 0.20 & 0.93 & 3.47 & 4.60 \\
\hline Halo + met & $\mathrm{POST}+\mathrm{PRE}$ & $48+550$ & 0.84 & 1.05 & 6.31 & 8.20 & 0.25 & 0.45 & 3.95 & 4.63 \\
\hline$(S)$-Metolachlor ( $S$-met) & PRE & 1020 & 0.62 & 0.93 & 6.95 & 8.50 & 0.23 & 0.42 & 4.25 & 4.9 \\
\hline$S$-met + halo & $\mathrm{PRE}+\mathrm{POST}$ & $1020+48$ & 0.64 & 0.99 & 7.02 & 8.65 & 0.26 & 0.54 & 3.98 & 4.78 \\
\hline P-value & - & - & 0.2521 & 0.0022 & 0.0281 & 0.1524 & 0.6210 & 0.0009 & 0.8215 & 0.1256 \\
\hline Coefficient of variation, $\%$ & - & - & 3.9 & 1.9 & 8.8 & 4.6 & 7.5 & 6.9 & 9.7 & 4.8 \\
\hline
\end{tabular}

Tomatoes were graded prior to weighing as small $(5.4 \mathrm{~cm}<$ diameter $)$, large $(6.4 \mathrm{~cm}<$ diameter $<7.0 \mathrm{~cm})$ and $\mathrm{x}$-large $(>7.0 \mathrm{~cm})$. Marketable yield is the sum of the three fruit grades.

Means followed by different letters in each column are significantly different by Tukey’s protected LSD (P $\leq 0.05)$.

indicating that purple nut sedge emergence after this period would not result insignificant. Combining herbicides with different modes of action can prevent the evolution of herbicide-resistant weeds (Galon et al., 2018; Zargar et al., 2019b). Unfortunately, despite significant weed suppression, there was still a number of nut sedge plants that were able to survive and produce seeds; and this may complicate weed management practices in the future, especially when using active ingredients with a single mode of action.

Tomato fruit yield was significantly higher in 2015 than in 2016. Because of differences in climate and field condition at sowing date, tomato yields varied in the growing seasons of 2015 and 2016. POST halosulfuron (Jennings, 2010) and PRE (S)-metolachlor (Boyd, 2016) can be safely used in plasticulture tomato without negative impact on tomato productivity, as tomato is tolerant to these herbicides (Buker et al., 2004; Chintala et al., 2014). Application rates for herbicide treatments and also for weedy control are presented in Table 4.

Herbicides used in this research were selected because they are routinely used by farmers in the area. Overall, PRE transplant application of metribuzin and $(S)$-metolachlor alone did not provide significant or sufficient nut sedge reduction percent. POST transplant application of halosulfuron followed by the PRE transplant herbicides $(S)$-metolachlor or metribuzin tended to provide the highest weed suppression across both seasons.

\section{CONCLUSIONS}

According to our findings, these herbicide programs are safe to use on tomato plasticulture cultivation in Shahriar, Iran. Our results found that the combination of PRE and POST transplanting herbicides for purple nut sedge control are viable options in plasticulture tomato production. PRE metribuzin and $(S)$-metolachlor plus POST halosulfuron can provide sustainable nut sedge management in tomato fields. There was no differences in total marketable tomato, but, there was differences in diameter large in 2015 and 2016, and x-large in 2015. Overall, it is important reduce purple nut sedge shoots and this could impact future weed densities.

\section{ACKNOWLEDGEMENTS}

This paper has been supported by the RUDN University Strategic Academic Leadership Program.

\section{REFERENCES}

Adcock, C.W., Foshee, W.G., Wehtje, G.R., and Gilliam, C.H. 2008. Herbicide combinations in tomato to prevent nutsedge (Cyperus esculentus) punctures in plastic mulch for multicropping systems. Weed Technology 22:136-141.

Anonymous. 1991. United States standards for grades of fresh tomatoes. Available at https://www.ams.usda.gov/sites/default/ files/media/Tomato_Standard\%5B1\%5D.pdf (accessed 22 October 2017).

Bangarwa, S.K., Norsworthy, J.K., and Gbur, E.E. 2009. Cover crop and herbicide combinations for weed control in polyethylenemulched bell pepper. Horticulture Technology 19:405-410. 
Bayat, M., Engeribo, A., Meretukov, Z., Aigerim, A., Temewei, A.G., Dubrovina, T., et al. 2019. Response of common lambsquarters (Chenopodium album L.) to chemical weed control programs. Research on Crops 20:859-863.

Blum, R.R., Isgrigg, J., and Yelverton, F.H. 2000. Purple (Cyperus rotundus) and yellow nutsedge (C. esculentus) control in bermudagrass (Cynodon dactylon) turf. Weed Science 14:357-365.

Boyd, N.S. 2015. Evaluation of preemergence herbicides for purple nutsedge (Cyperus rotundus) control in tomato. Weed Technology 29:480-487.

Boyd, N.S. 2016. Pre- and postemergence herbicides for row middle weed control in vegetable plasticulture production systems. Weed Technology 30:949-957.

Boyd, N.S., and Dittmar, P. 2018. Evaluation of postemergence-directed herbicides for purple nutsedge (Cyperus rotundus) control in fresh-market tomato. Weed Technology 32:260-266.

Buckelew, J.K., Monks, D.W., Jennings, K.M., Hoyt, G.D., and Walls, R.F. 2006. Eastern black nightshade (Solanum ptycanthum) reproduction and interference in transplanted plasticulture tomato. Weed Science 54:490-495.

Buker, R.S., Rathinasabapathi, B., Stall, W.M., MacDonald, G., and Olson, S.M. 2004. Physiological basis for differential tolerance of tomato and pepper to rimsulfuron and halosulfuron: site of action study. Weed Science 52:201-205.

Chaudhari, S., Jennings, K., Monks, D.W., Jordan, D.L., Gunter, C., and Louws, F.J. 2015. Response of grafted tomato (Solanum lycopersicum) to herbicides. Weed Research 29:800-809.

Chintala, R., Mollinedo, J., Schumacher, T.E., Malo, D.D., and Julson, J.L. 2014. Effect of biochar on chemical properties of acidic soil. Archives of Agronomy and Soil Science 60:393-404.

Devkota, P., Norsworthy, J.K., and Rainey, R. 2013. Efficacy and economics of herbicide programs compared to methyl bromide for weed control in polyethylene-mulched tomato. Weed Technology 27:580-589.

Dittmar, P.J. 2013. Weed control strategies in tomato. The Florida Tomato Proceedings. p. 24. Available at https://swfrec.ifas.ufl . edu/docs/pdf/veg-hort/tomato-institute/proceedings/ti13_proceedings.pdf (accessed June 2014).

Dittmar, P.J., Jennings, K.M., and Monks, D.W. 2010. Response of diploid watermelon to imazosulfuron POST. Weed Technology 24:127-129.

Dittmar, P., Monks, D.W., and Jennings, K.M. 2012. Effect of drip-applied herbicides on yellow nutsedge (Cyperus esculentus) in plasticulture. Weed Technology 26:243-247.

Freeman, J.H., Vallad, G.E., and Dittmar, P.J. 2016. Vegetable production handbook of Florida 2016-2017. University of Florida, Vance Publishing, Gainesville, Florida, USA.

Galon, L., David, F.A., Forte, C.T., Radunz, A.L., Kujawinski, R., Radunz, L.L., et al. 2018. Chemical management of weeds in corn hybrids. Weed Biology and Management 17:22-41.

Garvey, P.V., Meyers, S.L., Monks, D.W., and Coble, H.D. 2013. Influence of Palmer amaranth (Amaranthus palmeri) on the critical period for weed control in plasticulture-grown tomato. Weed Technology 27:165-170.

Grichar, W.J., Besler, B.A., and Brewer, K.D. 2003. Purple nutsedge control and potato (Solanum tuberosum) tolerance to sulfentrazone and halosulfuron. Weed Technology 17:485-490.

Haar, M.J., Fennimore, S.A., McGiffen, M.E., Lanini, W.T., and Bell, C.E. 2002. Evaluation of preemergence herbicides in vegetable crops. HortTechnology 12:95-99.

Jennings, K.M. 2010. Tolerance of fresh-market tomato to postemergence directed imazosulfuron, halosulfuron and trifloxysulfuron. Weed Research 24:117-120.

Mafakheri, S., Zargar, M., and Fakhri, K. 2012. The best application time and dose of herbicide for optimum weed management in two red bean cultivars. Indian Journal of Science and Technology 5:1848-1850.

Manning, G.R., and Fennimore, S.A. 2001. Evaluation of low-rate herbicides to supplement methyl bromide alternative fumigants to control weeds in strawberry. HortTechnology 11:603-609.

Merino, J., Pedreros, A., Fischer, S., and López, M.D. 2020. Effect of post-emergence herbicides on stress indicators in quinoa. Chilean Journal of Agricultural Research 80:21-29. doi:10.4067/S0718-58392020000100021.

Miller, M.R., and Dittmar, P.J. 2014. Effect of PRE and POST-directed herbicides for season-long nutsedge (Cyperus spp.) control in bell pepper. Weed Research 28:518-526.

Pereira, W., Crabtree, G., and William, R.D. 1987. Herbicide action on purple and yellow nutsedge (Cyperus rotundus and C.esculentus). Weed Technology 1:92-98.

Pliushchikov, V., Bayat, M., Zargar, M., Akhrarov, M., Orujov, E., and Hassan, N.S. 2019. Common lambsquarters response to the ALS inhibitor herbicides. Research on Crops 20:706-710.

Shirdel, K., Amani, S., and Yarnia, M. 2014. Controlling Egyptian broomrape in tomato fields in Iran. Iran Journal of Field Crop Research 12:476-483.

Vasilakoglou, I., Dhima, K., and Gitsopoulos, T. 2018. Management of penoxsulam- and bispyribac-resistant late watergrass (Echinochloa phyllopogon) biotypes and rice sedge (Cyperus difformis) in rice. Chilean Journal of Agricultural Research 78:276-286. doi:10.4067/S0718-58392018000200276. 
Vencill, W.K., Richburg, J.S., Wilcut, J.W., and Hawf, L.R. 1995. Effect of MON-12037 on purple (Cyperus rotundus) and yellow (Cyperus esculentus) nutsedge. Weed Technology 9:148-152.

Yu, J., Sharpe, S.S., and Boyd, N.S. 2020. Preemergence herbicides and halosulfuron POST for purple nutsedge control in tomato grown in plasticulture systems. Weed Technology 1-5. doi:10.1017/wet.2020.24.

Zand, E., Nasiri, M., and Rashed, M. 2011. Response of Echinochloa crus-galli and Abotilon theophrasti to herbicides in greenhouse condition. Journal of Plant Protection 25(2): 202-213. In Persian.

Zargar, M., Bayat, M., Lyashko, M., and Chauhan, B. 2019b. Postemergence herbicide applications impact Canada thistle control and spring wheat yields. Agronomy Journal 111:2874-2880.

Zargar, M., Bayat, M., Romanova, E., and Izadi- Darbandi, E. 2019a. POST herbicide programs utilizing tribenuron for cleavers (Galium aparine L.) control in winter wheat cultivars. Archives of Agronomy and Soil Science 66(9):12351243. doi:10.1080/03650340.2019.1661995.

Zenga, C., Tana, P., and Liu, Z. 2020. Effect of exogenous ARA treatment for improving postharvest quality in cherry tomato (Solanum lycopersicum L.) fruits. Scientia Horticulturae doi.org/10.1016/j.scienta.2019.108959.

Zimdahl, R.L. 2004. Weed-crop competition: A review. $2^{\text {nd }}$ ed. Blackwell, San Diego, California, USA. 